MEDIKA ALKHAIRAAT : JURNAL PENELITIAN KEDOKTERAN DAN KESEHATAN 1(2): 64-68

e-ISSN: 2656-7822, p-ISSN: 2657-179X

\title{
GAMBARAN CT SCAN ATAU USG PENDERITA HEPATOMA YANG DIRAWAT DI RSU ANUTAPURA DAN RSUD UNDATA PALU PERIODE 2015-2017
}

\author{
Muhammad Zhafran Natsir ${ }^{1}$, Mukramin Amran ${ }^{1}$, Husna Livi ${ }^{1}$ \\ ${ }^{1}$ Program Studi Pendidikan Dokter, Fakultas Kedokteran Universitas Alkhairat, Jl. Diponegoro No. 39 Palu \\ 94221, Sulawesi Tengah, Indonesia \\ *Corresponding author: Telp: +6281524511350, email: a.mukramin@yahoo.com
}

\begin{abstract}
ABSTRAK
Hepatoma merupakan pertumbuhan sel hati yang tidak normal yang di tandai dengan bertambahnya jumlah sel dalam hati yang memiliki kemampuan membelah/mitosis disertai dengan perubahan sel hati yang menjadi ganas. Angka kejadian hepatoma di Indonesia cukup jarang namun memiliki dampak yang sangat besar. Gambaran CT Scan atau USG pada penderita hepatoma sangat penting untuk mendeteksi serta terapi yang tepat untuk mengatasi hepatoma. Tujuan penelitian ini adalah untuk mengetahui gambaran CT Scan atau USG pada penderita hepatoma berdasarkan jumlah nodul, lokasi lesi, dan metastasis. Metode penelitian bersifat deskriptif pada 38 data penderita hepatoma yang dirawat di RSU Anutapura dan RSUD Undata Palu Periode 2015-2017, untuk mengetahui distribusi gambaran CT Scan atau USG pada penderita hepatoma berdasarkan jumlah nodul, lokasi lesi, dan metastasis dengan cara memeriksa data rekam medik pasien. Pengolahan data menggunakan SPSS 21 untuk menghitung distribusi frekuensi ,masing-masing variabel. Hasil penelitian menunjukan bahwa distribusi gambaran CT Scan atau USG pada penderita hepatoma yang dirawat di RSU Anutapura dan RSUD Undata Palu Periode 2015-2017 adalah sebagai berikut (1) paling sering pada pasien laki-laki lansia akhir; pada pasien yang memiliki jumlah lesi lebih dari satu sebanyak 28 pasien (73,7\%); pada pasien yang memiliki lokasi lesi pada lobus kanan hepar sebanyak 32 pasien (84,2\%); pada pasien yang memiliki lesi yang bermetastasis sebanyak 20 pasien (52,6\%). Disimpulkan bahwa gambaran CT Scan atau USG pada penderita hepatoma yang dirawat di RSU Anutapura dan RSUD Undata Palu periode 2015-2017 ditemukan yang paling banyak memiliki jumlah lesi lebih dari satu, memiliki lesi pada lobus kanan hepar, dan lesi sudah bermetastasis.
\end{abstract}

Kata Kunci: gambaran CT Scan, USG, Hepatoma

\section{ABSTRACT}

Hepatoma is an abnormal growth of liver cells that is characterized by increase in the number of liver cells that have ability to divide accompanied by changes in liver cells that become malignant. The incidence of hepatoma in Indonesia is quite rare but has a large impact. CT scan or ultrasonography images in patients with hepatoma are very important to detect and appropriate therapy to treat hepatoma. The purpose of this study was to determine the CT scan or ultrasonography in hepatoma patients based on the number of nodules, location of the lesion, and metastasis. Descriptive research method on 38 data of hepatoma patients treated at Anutapura and Undata Hospital Palu in the 2015-2017 period, to determine the distribution of CT scan images or ultrasonography in hepatoma patients based on the number of nodules, lesion locations, and metastases by examining the patient's medical record data. Data processing uses SPSS 21 to calculate the frequency distribution of each variable. The results showed that the distribution of CT scan or ultrasonography images in hepatoma patients treated at Anutapura and Undata Hospital Palu 2015-2017 as follows (1) most often in late elderly male patients; in patients who had more than one lesion as many as 28 patients (73.7\%); 32 patients (84.2\%) had lesions in the right lobe of 
MEDIKA ALKHAIRAAT : JURNAL PENELITIAN KEDOKTERAN DAN KESEHATAN 1(2): 64-68

e-ISSN: 2656-7822, p-ISSN: 2657-179X

the liver. in patients who had metastatic lesions were 20 patients (52.6\%). It was concluded that the CT scan or ultrasonography image of hepatoma patients treated at Anutapura and Undata Hospital Palu in 2015-2017 period was found to have the most number of lesions more than one, had lesions in the right lobe of the liver, and lesions had metastasized.

Keywords: CT scan image, ultrasonography, hepatoma

\section{PENDAHULUAN}

Hepatoma disebut juga kanker hati atau karsinoma hepatoseluler atau karsinoma hepato primer. Hepatoma merupakan pertumbuhan sel hati yang tidak normal yang di tandai dengan bertambahnya jumlah sel dalam hati yang memiliki kemampuan membelah/mitosis disertai dengan perubahan sel hati yang menjadi ganas ${ }^{1}$.

Radiologi adalah bagian dari ilmu kedokteran yang menggunakan sinar, baik pengion maupun non pengion dan imajing (pencitraan) yang digunakan baik untuk mendiagnosa penyakit maupun untuk terapi suatu penyakit. Prevalensi di Indonesia berdasarkan diagnosis kanker maupun jenis kanker yang ditegakkan berdasarkan hasil wawancara terhadap pertanyaan pernah didiagnosis menderita kanker oleh dokter. Prevalensi kanker tertinggi terdapat di DI Yogyakarta $(4,1 \%)$, diikuti Jawa Tengah (2,1\%), Bali (2\%), Bengkulu, dan DKI Jakarta masing-masing 1,9 per mil. Kanker ini pula meningkat seiring dengan bertambahnya usia, tertinggi pada kelompok umur 55-64 tahun $(1,3 \%)$, menurun sedikit pada kelompok umur $65-74$ tahun $(3,9 \%)$ dan umur $\geq 75$ tahun $(5 \%)$. Status ekonomi hampir sama mulai kuintil indeks kepemilikan menengah bawah sampai teratas $(1,8 \%)$. Prevalensi di perdesaan lebih tinggi dibanding perkotaan $(1,7 \%)^{6}$. Hepatoma dapat terbentuk salah satunya dengan gambaran massa yang hyperekoik dan peningkatan kontras pada arteri yang menunjukan neovaskuler dari massa hati dengan densitas yang rendah tergantung pemeriksaan radiologi yang dilakukan. sehingga pasien merasakan nyeri atau perasaan tak nyaman dikuadran kanan-atas abdomen. ${ }^{2}$

\section{METODOLOGI}

Penelitian ini bersifat deskriptif yang bertujuan untuk mengetahui gambaran CT Scan atau USG penderita hepatoma yang dirawat di RSU Anutapura dan RSUD Undata periode 20152017. Penelitian ini dilakukan pada bulan Juli sampai dengan bulan Agustus 2018 di ruang rekam medik RSU Anutapura dan RSUD Undata.

Pada penelitian ini yang menjadi subyek adalah semua penderita hepatoma yang telah menjalani pemeriksaan radiologi USG atau CT Scan di RSU Anutapura dan RSUD Undata Palu periode Januari 2015-Desember 2017. Cara pengambilan sampel pada penelitian ini adalah "sampel jenuh" pada rekam medik pasien yang didiagnosa hepatoma dan telah melakukan pemeriksaan radiologi CT Scan atau USG di RSU Anutapura dan RSUD Undata Palu periode 2015-2017.

\section{Cara Pengambilan Sampel}

Cara pengambilan sampel pada penelitian ini adalah "sampel jenuh" pada rekam medik pasien yang didiagnosa hepatoma dan telah melakukan pemeriksaan radiologi CT Scan atau USG di RSU Anutapura dan RSUD Undata Palu periode 2015-2017.

\section{Prosedur Penelitian}

1. Peneliti meminta izin institusi atau direktur rumah sakit untuk melihat data rekam medik pasien yang terdiagnosis Hepatoma sebagai populasi penelitian.

2. Setelah izin diberikan pimpinan rumah sakit, peneliti akan mengambil data pasien yang terdiagnosis Hepatoma di Rekam medik Rumah sakit.

3. Kemudian peniliti akan mengumpulkan semua data yang telah diperoleh.

4. Data yang dikumpulkan dianalisis menggunakan program SPSS 21.0. 
MEDIKA ALKHAIRAAT : JURNAL PENELITIAN KEDOKTERAN DAN KESEHATAN 1(2): 64-68

e-ISSN: 2656-7822, p-ISSN: 2657-179X

5. Setelah analisis data selesai, peneliti melakukan penulisan hasil dan ditampilkan pada seminar proposal.

\section{Rencana analisis data}

1. Menggunakan deskriptif kategorik dengan hasil berupa frekuensi dan presentase (proporsi) yang dapat disajikan dalam bentuk tabel maupun grafik.

2. Dummy table

Hasil penelitian dari proposal diharapkan tercermin pada bagian dummytable

\section{HASIL DAN PEMBAHASAN} HASIL

Penelitian ini dilakukan di RSU Anutapura dan RSUD Undata Palu pada bulan April sampai juni 2018. Penderita hepatoma yang dirawat di RSU Anutapura dan RSUD Undata Palu yang memenuhi kriteria penelitian sebanyak 38 sampel. Pengumpulan data penelitian ini dilakukan dengan pengambilan data sekunder menggunakan dokumen penelitian. Adapun data yang diperoleh terdiri dari jumlah lesi, lokasi lesi, dan metastasis. Hasil analisa statistik ditampilkan dengan sistematika sebagai berikut:

Tabel 1. Karakteristik jenis kelamin dan usia pada penderita hepatoma periode Januari 2015 Desember2017.

Jenis kelamin

\begin{tabular}{|l|c|c|}
\hline Jenis Kelamin & $\mathrm{N}$ & $\%$ \\
\hline -Laki-laki & 30 & $78,9 \%$ \\
-Perempuan & 8 & $21,1 \%$ \\
Total & 38 & $100,0 \%$ \\
\hline
\end{tabular}

Usia
\begin{tabular}{|l|c|c|}
\hline Usia & $\mathrm{N}$ & $\%$ \\
\hline$-17-25$ tahun & 0 & $0 \%$ \\
$-26-35$ tahun & 0 & $0 \%$ \\
$-36-45$ tahun & 5 & $13,2 \%$ \\
$-46-55$ tahun & 12 & $32,2 \%$ \\
$-56-65$ tahun & 16 & $41,4 \%$ \\
$>66$ tahun & 5 & $13,2 \%$ \\
Total & 38 & $100,0 \%$ \\
\hline
\end{tabular}

Berdasarkan tabel diatas, hasil dari 38 penderita hepatoma yang dirawat di RSU Anutapura dan RSUD Undata palu periode januari 2015- desember 2017 yang memenuhi kriteria penelitian pada jenis kelamin adalah sebagian besar pada jenis kelamin laki-laki yaitu sebesar 30 orang $(78,9 \%)$ dan perempuan 8 orang $(21,1 \%)$. Kriteria penelitian pada usia ditemukan terbanyak pada usia 56-65 tahun yaitu sebanyak 16 orang $(41,4 \%)$, usia $46-55$ tahun 12 orang $(32,2 \%)$, usia $36-45$ dan usia lebih dari 65 tahun sebanyak 5 orang $(13,2 \%)$, sedangkan pada usia 17-35 tidak didapatkan penderita hepatoma $(0 \%)$.

a. Distribusi gambaran radiologi CT Scan atau USG penderita hepatoma berdasarkan Jumlah lesi.

Distribusi gambaran radiologi CT Scan atau USG penderita hepatoma berdasarkan jumlah lesi dapat dilihat pada tabel berikut :

Tabel 2. Distribusi gambaran radiologi CT Scan atau USG penderita hepatoma berdasarkan jumlah lesi periode Januari 2015 Desember2017.

\begin{tabular}{|l|c|c|}
\hline Jumlah Lesi & $\mathrm{N}$ & $\%$ \\
\hline -Berjumlah 1 & 10 & $26,3 \%$ \\
-Lebih dari 1 & 28 & $73,7 \%$ \\
Total & 38 & $100,0 \%$ \\
\hline
\end{tabular}

Berdasarkan tabel diatas, hasil dari 38 penderita hepatoma yang dirawat di RSU Anutapura dan RSUD Undata palu periode januari 2015- desember 2017 jumlah lesi yang terbanyak yaitu berjumlah lebih dari satu sebesar $28(73,7 \%)$ dan yang berjumlah 1 sebesar $10(26,3 \%)$.

\section{b. Distribusi gambaran radiologi CT Scan atau USG penderita hepatoma berdasarkan Lokasi Lesi.}

Distribusi gambaran radiologi CT Scan atau USG penderita hepatoma berdasarkan lokasi lesi dapat dilihat pada tabel berikut : 
MEDIKA ALKHAIRAAT : JURNAL PENELITIAN KEDOKTERAN DAN KESEHATAN 1(2): 64-68

e-ISSN: 2656-7822, p-ISSN: 2657-179X

Tabel 3. Distribusi gambaran radiologi CT Scan atau USG penderita hepatoma berdasarkan lokasi lesi periode Januari 2015 Desember2017.

\begin{tabular}{|l|c|c|}
\hline Lokasi Lesi & $\mathrm{N}$ & $\%$ \\
\hline -Lobus kanan & 32 & $84,2 \%$ \\
-Lobus kiri & 6 & $15,8 \%$ \\
Total & 38 & $100,0 \%$ \\
\hline
\end{tabular}

Berdasarkan tabel diatas, hasil dari 38 penderita hepatoma yang dirawat di RSU Anutapura dan RSUD Undata palu periode januari 2015- desember 2017 lokasi lesi yang terbanyak yaitu dilobus kanan sebesar 32 $(84,2 \%)$ dan yang dilobus kiri sebesar 6 $(15,8 \%)$.

c. Distribusi gambaran radiologi CT Scan atau

USG penderita hepatoma berdasarkan Metastasis.

Distribusi gambaran radiologi CT Scan atau USG penderita hepatoma berdasarkan metastasis dapat dilihat pada tabel berikut :

Tabel 4. Distribusi gambaran radiologi CT Scan atau USG penderita hepatoma berdasarkan metastasis periode Januari 2015 Desember2017.

\begin{tabular}{|l|c|c|}
\hline Metastasis & N & $\%$ \\
\hline -Ada & 20 & $52,6 \%$ \\
-Tidak ada & 18 & $47,4 \%$ \\
Total & 38 & $100,0 \%$ \\
\hline
\end{tabular}

Berdasarkan tabel diatas, hasil dari 38 penderita hepatoma yang dirawat di RSU Anutapura dan RSUD Undata palu periode januari 2015- desember 2017 didapatkan hasil yang terbanyak yaitu lesi yang bermetastasis sebesar $20 \quad(52,6 \%)$ dan yang tidak bermetastasis sebesar $18(47,4 \%)$.

\section{PEMBAHASAN}

1. Distribusi gambaran CT Scan atau USG penderita hepatoma berdasarkan jumlah lesi

Dari hasil penelitian pada 38 penderita hepatoma yang dirawat di RSU Anutapura dan
RSUD Undata Palu periode Januari 2015 Desember 2017 berdasarkan jumlah lesi didapatkan terbanyak yang berjumlah lebih dari satu sebesar 73,7\%. Hal ini sejalan dengan penelitian yang dilakukan oleh Andreas Schiho, Pereira LP, Haimerl M, et-al pada tahun 20102015 pada pasien hepatoma didapatkan sebesar $56,0 \%$ yang memiliki jumlah lesi lebih dari satu.

\section{Distribusi gambaran CT Scan atau USG penderita hepatoma berdasarkan lokasi.}

Dari hasil penelitian pada 38 penderita hepatoma yang dirawat di RSU Anutapura dan RSUD Undata Palu periode Januari 2015 Desember 2017 berdasarkan lokasi lesi didapatkan terbanyak berada di lobus kanan sebesar $84,2 \%$. Hal ini sejalan dengan teori Terese Winslow pada tahun 2010 yang menyatakan bahwa penderita hepatoma lebih sering merasakan nyeri pada bagian kanan atas perut, yang menandakan bahwa lokasi lesi sebagian besar berada pada lobus kanan hepar, yang berarti lobus kanan lebih besar dan memiliki vaskularisasi lebih banyak dibandingkan dengan lobus kiri sehingga sel kanker mudah berkembang. ${ }^{6}$

\section{Distribusi gambaran CT Scan atau USG penderita hepatoma berdasarkan metastasis.}

Dari hasil penelitian pada 38 penderita hepatoma yang dirawat di RSU Anutapura dan RSUD Undata Palu periode Januari 2015 Desember 2017 berdasarkan metastasis didapatkan 52,6\%. Hal ini sejalan dengan penelitian yang dilakukan oleh Annalisa k, Becker MD, David K, et al pada tahun 2014 yang menyatakan bahwa hepatoma ekstrahepatik dapat terjadi dalam 3 cara: perluasan langsung, penyebaran hematogen, atau invasi limfatik. Frekuensi yang dilaporkan metastasis ke paru (55\%), kelenjar getah bening (53\%), tulang (28\%), kelenjar adrenal (11\%), peritoneum $(11 \%)$ dan otak $(2 \%) .^{5}$ 
Berdasarkan hasil penelitian pada 38 penderita hepatoma yang berobat di RSU Anutapura dan RSUD Undata palu dapat disimpulkan bahwa: Distribusi gambaran CT scan atau USG pada penderita hepatoma berdasarkan jumlah lesi terbanyak yang berjumlah lebih dari satu sebesar 28 pasien $(73,7 \%)$. Distribusi gambaran CT scan atau USG pada penderita hepatoma berdasarkan lokasi terbanyak terdapat pada lobus kanan sebesar 32 pasien $(84,2 \%)$.

\section{DAFTAR PUSTAKA}

1. Cicale L. Hepatocelullar Carcinoma in Geibel J. Editor. Texas :Texas Transplant Center and Hepatobiliary Surgery. 2016 Dec 22: 1-7.

2. Jacobson DR. Hepatoceluller Carcinoma Imaging.Medscape. 2016 Apr 8: 1-2.

3. Kementrian Kesehatan Republik Indonesia. Riset Kesehatan Dasar. Indonesia. 2013: 86-87.

4. Schicho A, Pereira LP, Haimerl M, et-al. Transarterial chemoembolization (TACE) with degradable starch microspheres (DSM) in hepatoceluller carcinoma.Oncotarget. 2017;42(8): 7261320.

5. Annalisa K, Becker MD, David K, et-al. Extrahepatic Metastases of Hepatoceluller Carcinoma: A Spectrum of imaging findings.Canadian Association of Radiologist Journal.2014 February, 1:65: 60-6.

6. Winslow, T. Liver Cancer. Center for Disease Control and Prevention. 2010. 